\title{
FEEDING ECOLOGY OF TREE-CLIMBING MANGROVE SESARMID CRABS FROM LUZON, PHILIPPINES
}

\author{
JIMMY TEVAR MASAGCA \\ De La Salle University-Dasmariñas \\ Cavite 4115, The Philippines
}

\begin{abstract}
Despite the large ecological study of tree-climbing mangrove sesarmid crabs in other countries, the Philippine representatives appear to have not been investigated extensively. This paper presents the feeding ecology as to dependence on mangrove trees of sesarmids in different mangrove areas of southern Luzon. This is biased on the nature of the crab habitats, arboreal climbing skills and burrowing behavior of the sesarmids: Selatium elongatum and Episesarma versicolor - exclusive mangrove tree climbers (EMTC); Sarmatium germaini occasional mangrove tree climber (OMTC); and the non-mangrove tree-climbing (NMTC) sesarmids- Neosarmatium smithii, Perisesarma bidens and Perisesarma eumolpe.
\end{abstract}

Key words: mangrove crabs, sesarmid crabs, climbing skills, burrowing skills, arboreal climbing crabs, Catanduanes, Philippines

\section{INTRODUCTION}

The crustaceans (e.g. brachyurans) are always a prominent and diverse element of the fauna in mangals (Morton 1990). Crabs are diverse in mangrove habitats and abundant in many mangals (Jones 1984). Several authors (e.g. Jones 1984, Lee 1998) have attested that brachyurans are important in the mangrove ecosystem structure and function. Unfortunately, it appears that there is still a dearth of detailed published information on the occurrence of several families of this group of crustaceans in the mangrove areas of the Philippines. Moreover, there seems to be limited published data on the ways in which these faunal elements use the mangrove resources. The sesarmids are less documented in the Philippines unlike in other countries, wherein several reports are available from Singapore (Sivasothi 2000; Sivasothi et al. 1993; Tan \& Ng 1994; Ng \& Liu 1999) Malaysia (Tan \& Ng 1994; Leh \& Sasekumar 1985), Indonesia (Soemodihardhjo \& Soerianegara 1989; Rahayu \& Davie 2002), Hong Kong (Poovatchiranon 1986; Lee \& Leung 1993; Lee 1998; Lee 1997; Kwok 1995; Kwok \& Tang 2005; and Ashton 2002).

Crabs have different functions and impacts on the mangrove ecosystem. Firstly, they can process as much as $70 \%$ of the leaf litter, and leaf processing can turn over a litter at a rate in excess of 75 minutes (see studies of Leh \& Sasekumar, 1985; Slim

*Corresponding author: jtmasagca@dasma.dlsu.edu.ph, jmasagca@yahoo.com. 
et al. 1997; Dahdouh-Guebas et al. 1999; Ashton 2002). Secondly, most mangrove crabs feed on vascular plant materials, but they also feed on green leaves (Lee 1998; Skov \& Hartnoll 2002), including seedlings. Mangrove plant seedlings grazing, particularly in the genus Sesarma may also slow regeneration of mangroves. On the other hand, grapsoid crabs are the primary seed operators. Emmerson \& McGwynne (1992) described the feeding and assimilation of mangrove leaves by the crab Sesarma meinerti. Moreover, the feeding ecology of Neosarmatium smithii was studied by Giddins et al. (1986) and new records from Taiwan on this sesarmid crab was reported by Naruse et al. (2006).

The crabs of the family Sesarmidae are known by various workers to have significant ecological role in mangals (Lee 1998, Gillikin 2000; Gillikin \& Schubart 2004, Gillikin et al. 2004). Many species of these mangrove crabs do not assimilate much carbon from the mangrove leaves but rely on the sediments (Bouillon et al. 2002, Skov \& Hartnoll 2002). Some species of the genus Perisesarma supplement their diet with leaves (Leh \& Sasekumar 1985, Slim et al. 1997). Hence, this aspect on the feeding ecology of sesarmid crabs helps to trap the energy stored in these leaves within the mangal before the tide can carry them away ( Lee 1998; Skov \& Hartnoll 2002).

Despite the large ecological study of mangrove sesarmids in other countries (Bright \& Hogue 1972; Hartnoll 1975; Micheli, Gherardi \& Vannini 1991; Cannicci et al. 1996; Slim et al. 1997; Dahdouh-Guebas et al. 1999; Fratini, Cannicci \& Vannini 2000, Flores et al. 2003) the Philippine representatives appear to have not been investigated extensively. This study on the patterns of biodiversity in aquatic systems of the Philippines attempted to determine the feeding ecology of selected taxa of sesarmids as to (a) the nature of the crab habitats in the mangrove forest with reliance to the mangrove trees, trunks, roots, and leaves that offer a wide variety of ecological niches for the species under consideration; and (b) the behavior of the sesarmid crabs as revealed by their burrowing abilities and tree-climbing skills needed to explain the reliance of these crabs on the mangrove forest.

\section{MATERIALS AND METHODS}

\section{Study sites}

The collection and observation sites of the study include: I- Palsabangon Mangrove Area in Pagbilao, Quezon, Philippines; II - Maqueda Channel in the Bicol Region, Agojo Inlet Mangrove Reserve Area, San Andres and Palnab-Pajo Mangrove Area, Catanduanes, Philippines.

\section{Feeding ecology as to dependence on mangroves, arboreal climbing skills and burrowing behavior}

Specimens of mangrove crabs were collected by handpicking and with the use of scoop nets and locally made traps. Collections were made both in the morning and in the evening from the mangrove areas along rivers, creeks, inlets and the buffer zones or marginal strips of the coastline in one site each for the study areas from June 2005 to February 2006. 
Ecological studies on feeding behavior took place in the purposively selected study plots in Palnab-Pajo Mangrove Swamp, Catanduanes during the months of October and December in 2005, while in the mangrove areas of Palsabangon in Pagbilao, Quezon studies were done from January to February 2006. Ecological studies of sesarmids were carried out in each of the mangrove areas following the methods of Gillikin (2000). In the selected mangrove forests, presence or absence of crab species were determined by visual inspection in $10 \mathrm{~m}$ diameter plots along a transect perpendicular to the coastline, covering the full width of the forest. The study investigated at least 10 plots along a 100 to $200 \mathrm{~m}$ long transect in the areas under study.

\section{Emergence and re-emergence of the sesarmids}

During fieldwork, each plot was first inspected using binoculars from a distance of approximately $6 \mathrm{~m}$ for $20 \mathrm{~min}$. and the crab species recognized were noted and recorded. Afterwards, naked eye observations were undertaken with two field workers (observers) sitting on opposite sides of the plot for at least $30 \mathrm{~min}$, following Hartnoll et al. (2002) and Skov et al. (2002). As a modification, the researcher and field assistants were positioned in two separate paddled boats ("banca") when the plots were observed. The researcher approached the plot and a disturbance was created (either by throwing some mud, twigs or branches of mangrove plants) so that the sesarmids, under study take refuge in the burrows, or holes, and other materials to take cover (e.g. leaves, wood, twigs etc.). The time at which the first individual of the sesarmids will emerge or re-emerge was recorded. Observations for this portion of the study were undertaken during the day at low tides. Diurnal and lunar cycles were not used in the distinction of the observation. The aforementioned procedures are modifications of the works of Gillikin (2000), Hartnoll et al. (2002) and Skov et al. (2002).

\section{RESULTS AND DISCUSSIONS}

\section{Reliance on the mangroves as habitats}

Table 1 shows the summary of the observations made on the habitats of various grapsoid sesarmid crabs in the mangals of Catanduanes Island and Pagbilao, Quezon. The nature of their habitat, climbing abilities and burrowing skills could explain the feeding ecology of the mangrove crabs under investigation.

Table 1. Summary of the Feeding Ecology of Grapsoid Sesarmid Crabs from Different Mangals in Luzon

\begin{tabular}{ccl}
\hline $\begin{array}{c}\text { Grapsoid Sesarmid } \\
\text { Species }\end{array}$ & $\begin{array}{c}\text { Behavior/Nature of Habitat } \\
\text { Related to Feeding }\end{array}$ & \multicolumn{1}{c}{ Remarks on field observations } \\
\hline Episesarma versicolor & $\begin{array}{l}\text { Burrower and exclusive mangrove } \\
\text { tree climbing (EMTC) species }\end{array}$ & $\begin{array}{l}\text { Migrating from burrows to the tree stems and } \\
\text { some at the canopies; constructs burrows around } \\
\text { soft sediments of mangrove roots and tree trunks; } \\
\text { seen feeding on calyx and leaves; seen cropping on } \\
\text { leaf litters and bringing fragments to the burrows. }\end{array}$ \\
\hline
\end{tabular}


Table 1. Continued

\begin{tabular}{|c|c|c|}
\hline Selatium germaini & $\begin{array}{l}\text { Occasional mangrove tree climber } \\
\text { (OMTC) species }\end{array}$ & $\begin{array}{l}\text { Climbs on the branches of } R \text {. apiculata and } R \text {. } \\
\text { mucronata in the mangroves of Catanduanes. }\end{array}$ \\
\hline Neosarmatium smithi & $\begin{array}{l}\text { Burrower and Non-mangrove } \\
\text { tree climbing (NMTC) species }\end{array}$ & $\begin{array}{l}\text { Constructing burrows on mudflats; } \\
\text { Not seen climbing on stems of mangrove trees in } \\
\text { Quezon and Catanduanes }\end{array}$ \\
\hline Perisesarma bidens & $\begin{array}{l}\text { Burrower and Non-mangrove } \\
\text { tree climbing (NMTC) species }\end{array}$ & $\begin{array}{l}\text { Seen resting on Rhizophora tree (just within the } \\
\text { water lining) during high tide apparently for } \\
\text { avoidance and possibly for feeding purposes; also } \\
\text { seen hiding on rocks, crevices of boulders and tree } \\
\text { falls. }\end{array}$ \\
\hline Perisesarma eumolpe & $\begin{array}{l}\text { Burrower and Non-mangrove } \\
\text { tree climbing (NMTC) species }\end{array}$ & $\begin{array}{l}\text { On rare occasions, some crab samples were caught } \\
\text { on the trunks possibly carried by water current } \\
\text { during high tides. }\end{array}$ \\
\hline Selatium elongatum & $\begin{array}{l}\text { Arboreal climber or EMTC in } \\
\text { mangrove trunks, branches and } \\
\text { canopies }\end{array}$ & $\begin{array}{l}\text { Seen on main branches of Rhizophora; on aerial } \\
\text { roots; also on crevices of trunks. }\end{array}$ \\
\hline
\end{tabular}

Episesarma versicolor feed on calyx and leaves and crop on leaf litters, then bring fragments to the burrows. The grapsoid sesarmid crabs, Perisesarma spp. and Episesarma sp. were found to be herbivores and omnivore/deposit feeders, eating mangrove litter and water plants. Moreover, the sesarmid crabs Sarmatium germaini (Figure 1), Perisesarma eumolpe and Neosarmatium smithi feed on the mangrove litter, composed of fallen mangrove leaves of Rhizophora, seedlings, calyx and twigs that fall from the trees on the forest floor and into the water. This study confirmed that the leaves of the mangroves, $R$. marina, $R$. apiculata, and Ceriops tagal were devoured by the generally observed herbivorous/omnivorous crabs such as Perisesarma spp. The feeding habits of mangrove crabs have been divided into seven groups by Jones (1984): herbivore, carnivore, omnivore, deposit feeder, omnivore/deposit feeder, specialized filterer, and filterer/omnivore. In the study of Islam \& Uehara (2005), stomach content analysis showed that $P$. bidens diet consists mainly of mangrove leaves fragments, with small amounts of animal, algae and sediment matters, indicating that this sesarmid is primarily detritivorous.

In Chiromanthes onychophorum, Malley (1998) noted that this sesarmid crab consumes fallen leaves or their fragments, incompletely digests them, and returns them to the environment as fecal matter in a more finely-divided state than when they were ingested. Of recent, Ya et al. (2008) reported that both Perisesarma eumolpe and $P$. indiarum are mainly sediment grazers, but also feed on mangrove leaves and roots and occasionally animal matter. These crab species prefer Avicennia alba leaves to other mangrove species, i.e., A. officinalis, A. rumphiana, $R$. apiculata and Bruguiera gymnorbiza.

Dahdouh- Guebas (1997), Ashton (2002), Buck et al. (2003), Thongtham \& Kristensen (2003) and Schwamborn et al. (2006) analyzed the diets of sesarmid crabs showed that their diet mainly consisted of mangrove leaves and in addition to bustle animal matter. 


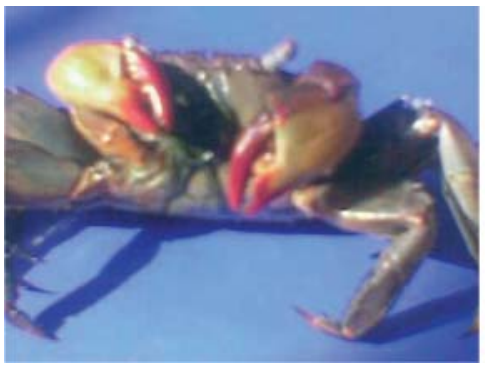

A.

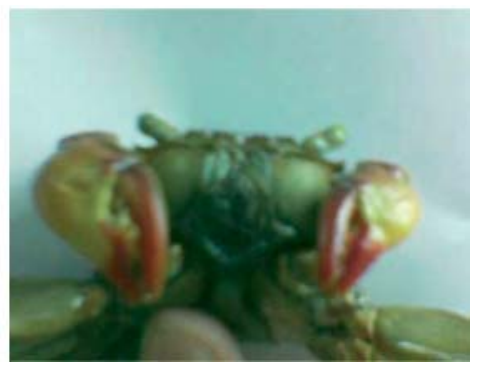

B.

Figure 1. Sarmatium germaini from Palsabangon Mangrove Area in Pagbilao, Quezon (A) and PalnabPajo Mangrove Swamp, Maqueda Channel, in Bicol Region (Catanduanes) (B).

\section{Burrowing and arboreal climbing skills of sesarmids}

Similar with other sesarmids, $P$. bidens are burrowers, but observations made in Quezon and Catanduanes indicate that some individuals tend to hide in natural refuges found in the mangals investigated. These hiding places are the crevices of rocks and boulders and in between portions of root buttresses of mangrove trees.

Field observation in Quezon, indicates that these crabs are also having preferences in arboreal environments wherein Selatium elongatum and Episesarma versicolor were seen clinging on mangrove stems or rush to the mangrove stems when disturbed, while the boat is cruising in the waterways. These tree climbing crabs appear to be less antagonized during the investigation and remained to be motionless for about 1 hour. When tides are rising or lowering, these crabs appear to be unaware as observed for at least an hour. However, when the rising tide reaches their location in any of the protruding branches of the mangrove trees in the embankments, these tree-climbing crabs tend to adjust or move slowly with their heads upside down. Researches indicate the possibility that these crabs cling to the mangrove stems not to find food but as avoidance from very long immersion in the water during high tides and due to the presence of predators. This could not be confirmed in the study. During field observation, it was rather easy to find $P$. bidens in the open sand or mudflats.

Behavioral differences between the male and female samples of $P$. bidens was observed. On the sexes, results of initial experiment suggest that there is no difference as to the aggressiveness. However, the males are more receptive to antagonistic encounters, especially when disturbed inside the aquarium prior to feeding observation. It was difficult for the researcher to catch this sesarmid due to its swiftness and alertness. One striking character of this crab is its fast action in retreating from external stimuli such as touch or other mechanical disturbance. This could be the reason why the feeding experiment did not proceed because the individuals of P. bidens placed in the glass aquaria did not feed on the pieces of $R$. apiculata, $R$. mucronata, A. marina and other associated mangrove plants.

However, the report of Ólafsson et al. (2002) cited that male and female crabs are likely to have different energy requirements, due to differences in the energetic costs of producing eggs or sperm (Michell 1993). A study of Kyomo (1992) conducted on the sesarmid crab Sesarma intermedia showed that females were more specialized in their feeding habits and had higher assimilation rates than males. 
$N$. smithii form burrows around $R$. mucronata and $R$. apiculata roots but rarely in Avicennia marina found in the mangals of Catanduanes. Observations indicate that $N$. smithi feed on leaf litter but also some shrimps, specifically Palaemonetes sp. This was observed during the afternoon hours when tides start to rise.

\section{Observation on emergence and re-emergence of sesarmids in the burrows}

In general, $P$. bidens appears to be the most active of the three sesarmids observed during the day. As shown in Table 2, the red-clawed grapsoid sesarmid crab, P. bidens emerged and re-emerged from the burrows much faster (mean of 3.48 mins) than the sesarmids N. smithi (mean of 4.15 mins) and E. versicolor (3.93 mins). All three sesarmid crab species display similar behavior of picking up the leaf fragments by first standing still in motionless for about 7 to 10 seconds. Some sesarmids, e.g $E$. versicolor has to consume the leaf fragment where they found it, then migrate for at leas 0.5 meters and to be continued at the mouth of the burrows. Some crabs move away from the areas where they got the leaf fragments and continue feeding near the burrows. Some bring these fragments inside the burrows but mostly will have the tendency to leave behind when disturbance was made.

There is much to be learned as to the sesarmid crab's feeding ecology in the Philippines since there are various similarities and differences in the findings of other authors. Some researchers report on the unusual presence or occurrence as to their level of dependence in the different habitats, arboreal or burrows. Climbing skills and burrowing abilities also vary depending on the species. While others focus on how sesarmids rush to the mangrove tree and and cling to the branches, it is still unknown whether they are apparently resting or catching some insects or invertebrates. Other researchers put premium on their occurrence in the mudflats or soft sediments of mangals for feeding on some leaf litter. Moreover, the sesarmids under study have been observed cropping and bustling on sand sediments and other fragments of leaf litter that some crab ecologists might have ignored and do not give emphasis. Further studies can be carried out in the future in terms of the feeding ecology of these vital species of mangrove crabs in relation to morphological variation of the feeding apparatus. Lastly, deeper reflections on the notions of convergent evolution (Fratinni et al. 2005) and the timing of development in relation to arboreal climbing skills and burrowing abilities of sesarmids deserve further attention.

Table 2. Data on the time of re-emergence of sesarmid crabs (P. bidens, N. smithi and E. versicolor) in burrows after disturbance

\begin{tabular}{|c|c|c|c|c|}
\hline \multirow{3}{*}{ Sesarmid Crab Species } & \multicolumn{3}{|c|}{ Time of Re-emergence } & \multirow{3}{*}{$\begin{array}{c}\text { MEAN TIME OF } \\
\text { RE-EMERGENCE (in } \\
\text { minutes) }\end{array}$} \\
\hline & \multicolumn{3}{|c|}{$\begin{array}{c}\text { Trials (Each consists of } 3 \text { repeats) } \\
\text { (in minutes) }\end{array}$} & \\
\hline & 1 & 2 & 3 & \\
\hline Perisesarma bidens & 3.35 & 3.65 & 3.45 & 3.4833 \\
\hline Neosarmatium smithi & 3.95 & 4.05 & 4.45 & 4.1500 \\
\hline Episesarma versicolor & 2.78 & 4.25 & 3.75 & 3.933 \\
\hline
\end{tabular}




\section{CONCLUSIONS}

Based on the results presented, Selatium elongatum and Episesarma versicolor are exclusive mangrove tree climbers (EMTC); Sarmatium germaini as occasional mangrove tree climber or OMTC; and the sesarmid species - Neosarmatium smithii, Perisesarma bidens and Perisesarma eumolpe as non-mangrove tree climbers or NMTC. The sesarmid species, E. versicolor, $N$. smithii, P. bidens and P. eumolpe posses burrowing skills, while $P$. bidens appeared to be the most active of the three sesarmids investigated.

\section{ACKNOWLEDGMENTS}

The author acknowledges with thanks to the administration of De La Salle University-Dasmariñas (DLSU -D) University Faculty Research Office (UFRO) Director Dr. J. Morta; Education Dean, Dr. O. Legaspi ; OIC VVice Chancellor, Dr. C. Cervillon; and DLSU-D Br. President Gus Boquer - for funding this research project on the mangrove crabs. Sincere thanks is also given to Dr. David Gillikin, Vrije Universiteit, T Brussel, Belgium and Dr. Peter K.L. Ng of the National University of Singapore for sending reprints on the mangrove crabs and Ms. Marivene Manuel, Philippine National Museum (PNM) for evaluating the earlier drafts of the report on this study. My special thanks to Elver Sison, while finalizing this paper. The assistance of my brother (Rico Masagca ); sisters (Tersy, Rosie, Elsie, Margie), and aunt (Mrs. Florida Tevar) is greatly appreciated during field observations in Catanduanes. Special thanks to the anonymous referees.

\section{REFERENCES}

Ashton E.C. 2002. Mangrove sesarmid crab feeding experiments in Peninsular Malaysia. Journal of Experimental Marine Biology and Ecology 273: 97-119.

Bouillon S., Koedam N. Raman A.V. and F. Dehairs .2002. Primary producers sustaining macro-invertebrate communities in inter-tidal mangrove forests. Oecologia, 130:441-448.

Bright D.B. and C.L. Hogue. 1972. A synopsis of the burrowing land crabs of the world and list of their symbionts and burrow associates. Contributions in Science-Los Angeles County Natural History Museum, 220: 1-58.

Cannicci S., Fratini S., and M. Vannini . 1999. Use of time and food resources in the mangrove climbing crab Selatium elongatum (Grapsidae: Sesarminae). Marine Biolology, 135: 335-339.

Dahdouh-Guebas F., Giuggioli M., Oluoch A., Vannini A. and S. Cannicci . 1999. Feeding habits of non-ocypodid crabs from two mangrove forests in Kenya. Bulletin of Marine Science , 64: 291-297.

Emmerson W.D. and L.E. McGwynne . 1992. Feeding and assimilation of mangrove leaves by the crab Sesarma meinerti de Man in relation to leaf-litter production in Mgazana, a warm-temperate southern African mangrove swamp. Journal of Experimental Marine Biology and Ecology, 157: 41-53. 
Emmerson W., Cannicci S. and F. Porri . 2003. New records for Parasesarma leptosoma (Hilgendorf, 1869) (Crustacea: Decapoda: Brachyura: Sesarmidae) from mangroves in Mozambique and South Africa. African Zoology, 38: 351-355.

Flores A.A.V., Paula J. and T. Dray. 2003. First zoeal stages of grapsoid crabs (Crustacea: Brachyura) from East African Coast. Zoological Journal of Linnean Society, 137:355-383.

Fratini S., Cannicci S. and M. Vannini. 2000. Competition and interaction between Neosarmatium smithii (Crustacea, Grapsidae) and Terebralia palustris (Mollusca, Gastropoda) in a Kenyan mangrove. Marine Biology, 137: 309-316.

Fratini S., Vannini M., Cannicci S. and C.D. Schubart . 2005. Tree-climbing mangrove crabs: a case of convergent evolution. Evolutionary Ecology Research, 7:219-233.

Giddins R.L., Lucas J.L., Nelson M.J. and G.N. Richards. 1986. Feeding ecology of the mangrove crab, Neosarmatium smithii (Crustacea:Decapoda: Sesarmidae). Marine Ecology Progress Series 33:147-155.

Gillikin D.P. 2000. Factors controlling the distribution of Kenyan brachyuran mangrove crabs: salinity tolerance and ecophysiology of two Kenyan Neosarmatium species. Unpublished MSc. Thesis, Vrije Universiteit Brussel, Belgium.

Gillikin D.P. and C.D. Schubart. 2004. Ecology and systematics of mangrove crabs of the genus Perisesarma (Crustacea: Brachyura: Sesarmidae) from East Africa. Zoological Journal of the Linnean Society, 141: 435-445.

Gillikin D.P., De Wachter B. and J.F. Tack . 2004. Physiological responses of two ecologically important Kenyan mangrove crabs exposed to altered salinity regimes. Journal of Marine Biology and Ecology, 301: 93-109.

Hartnoll R.G. 1975. The Grapsidae and Ocypodidae (Decapoda: Brachyura) of Tanzania. Journal of Zoology, 177: 305-328.

Hartnoll R.G. 1988. Evolution, systematics and, geographical distribution. In Biology of the Land Crabs (W.W. Burggren and B.R. McMahon, eds.), pp. 6-54. Cambridge: Cambridge University Press.

Hartnoll R.G., Cannicci S., Emmerson W.D., Fratini S., Macia A., Mgaya Y., Porri F, Ruwa R.K., Shunula J.P., Skov M.W. and M. Vannini. 2002. Graphic trends in mangrove crab abundance in East Africa. Wetlands Ecology and Management, 10: 203-213.

Jones D.A. 1984. Crabs of the mangal ecosystem. In: F. D. POR \& I. DOR (eds.), Hydrobiology of the Mangal: 89-109. (Dr. W. Junk Publishers, The Hague).

Khan S.A., Raffi S.M. and P.S. Lyla. 2005. Brachyuran crab diversity in natural (Pitchavaran) and artificially-developed mangroves (Vellar estuary). Current Science, 88(8):1316-1324.

Kwok P.W. 1995. The ecology of two sesarmine crabs, Perisesarma bidens (De Haan) and Parasesarma plicata (Latreille) at the Mai Po Marshes Nature Reserve, Hong Kong. Ph.D. thesis. University of Hong Kong.

Kwok W.P.W. and Wingsze Tang. 2005. An introduction to the common Sesarmine crabs of Hong kong. Issue No. 9. September. Retrieved on January 12, 2006. URL: http://www.hkbiodiversity. net/newsletters/HKBOnewsletter9.pdf.

Kyomo J. 1992. Variations in the feeding habits of males and females of the crab Sesarma intermedia. Marine Ecology Progress Series, 83: 151-155.

Leh C.M.U. and A. Sasekumar . 1985. The food of sesarmid crabs in Malaysian mangrove forests. Malayan Nature Journal, 39:135-145.

Lee S.Y. 1989. The importance of sesarminae crabs Chiromanthes spp. and inundation frequency on turnover in a Hong Kong tidal shrimp pond. Journal of Experimental Marine Biology and Ecology, 131:23-43. 
Feeding ecology of tree climbing mangrove sesarmid crabs - Jimmy T. Masagca

Lee S.Y. 1997. Potential trophic importance of the faecal material of the mangrove sesarmine crab Sesarma messa. Marine Ecology Progress Series, 159: 275-284.

Lee S.Y. 1998. Ecological role of grapsid crabs in mangrove ecosystems: a review. Marine and Freshwater Research 49: 335-343.

Lee S.Y. and V. Leung . 1993. The brachyuran fauna of the Mai Po Marshes Nature Reserve and Deep Bay, Hong Kong. The Mangrove Ecosystem of Deep Bay and the Mai Po Marshes, Hong Kong. Proceedings of the International Workshop on the Mangrove Ecosystem of Deep Bay and the Mai Po Marshes, Hong Kong 1993: 57-82.

Malley, D.F. 1998. Degradation of mangrove leaf litter by the tropical sesarmid crab Chiromanthes onychophorum. Marine Biology, 49(4):377-386.

Micheli F. 1993. Effect of mangrove litter species and availability on survival, moulting, and reproduction of the mangrove crab Sesarma messa. Journal of Experimental Maine Biology and Ecology, $171: 149-163$

Morton J. 1990. The shore ecology of the tropical Pacific. UNESCO ROSTSEA.

Naruse T., Lee J.H. and H.T. Shih. 2006. Two new records of shallow-water and mangrove crabs (Crustacea: Decapoda: Brachyura) from Taiwan. College Research, 19: 17-21.

Ng P.K. and H.C. Liu. 1999. The taxonomy of Sesarma tangi Rathbun, 1931 and S. stormi De Man, 1895 (Crustacea: Decapoda: Brachyura: Grapsidae: Sesarminae), with establishment of a new genus for S. stormi. Zoological Studies 38(2): 228-237.

Ólafsson Emil, S. Buchmayer and Martin W. Skov. 2002. The East African decapod crab Neosarmatium meinerti (de Man) sweeps mangrove floors clean of leaf litter. AMBIO: A Journal of the Human Environment, 31(7)569-573.

Poovachiranon S. 1986. The food of Chiromanthes bidens (De Haan, 1835) and C. maipoensis (Soh, 1978) (Decapoda: Sesarminae) from Hong Kong mangroves. In The marine flora and fauna of Hong Kong and southern China (ed. B. Morton and C.K. Tseng), 727-35. Proceedings of the Second International Marine Biological Workshop: The Marine Flora and Fauna of Hong Kong and Southern China, Hong Kong, 2-24 April 1986. Hong Kong: Hong Kong University Press.

Rahayu D.L. and P.D.F. Davie. 2002. Two new species and a new record of Perisesarma (Decapoda: Brachyura: Grapsidae: Sesarminae) from Indonesia. Crustaceana 75: 597-607.

Ravichandran S., A. Anthonisamy, T. Kannupandi and T. Balasubramanian.2007. Leaf choice of herbivorous mangrove crabs. Research Journal of Environmental Sciences, 1 (1): 26-30.

Sasekumar A., Chong V. and K.H. Lim. 1994. Status of mangrove finfish resources in ASEAN. In: C.R. Wilings S. Sudara and C.L. Ming (eds.) Proceedings of the 3rd ASEAN-Australian Symposium on the Living Coastal Resources held at Chulalongkorn University, Thailand 16-20 May.

Sivasothi N., D.H. Murphy and Ng P.K.L. 1993. Tree-climbing and herbivory of crabs in the Singapore mangroves. In Sasekumar, A. (ed.), Mangrove fisheries and connections. ASEAN-Australia Marine Science Project: Living Re-sources (Malaysia), Kuala Lumpur, Malaysia. p. 220-237.

Sivasothi N. 2000. Niche preferences of tree-climbing crabs of Singapore. Crustaceana, 73: 26-38.

Sivasothi N., Murphy D.H. and Ng PKL. 1993. Tree climbing and herbivory of crabs in the Singapore mangroves. In Mangrove Fisheries and Connections. Proceedings of the ASEAN-Australian Marine Science Project: Living Coastal Resources Workshop1 (A. Sasekumar, ed.), p. 220-237. Ipoh, Malaysia.

Skov M.W. and R.G.Hartnoll . 2002. Paradoxical selective feeding on a low nutrient diet: why do crabs eat leaves? Oecologia, 131:1-7. 
Skov M.W., Vannini M., Shunula J.P., Hartnoll R.G. and S. Cannicci. 2002. Quantifying the density of mangrove crabs: Ocypodidae and Grapsidae. Marine Biology, 141: 725-732.

Slim F.J., Hemminga M.A., Ochieng C., Jannink N.T., Cocheret de la Morinière E. and G. van der Velde. 1997. Leaf litter removal by the snail Terebralia palustris (Linnaeus) and sesarmid crabs in an East African mangrove forest (Gazi Bay, Kenya). Journal of Experimental Marine Biology and Ecology, 215: 35-48.

Soemodihardjo S. and I. Soerianegara. 1989. The status of mangrove forests in Indonesia, pp 73-114. In: Ishemat Soerianegara et al. (eds.), Proceedings of a Symposium on Mangrove Management: Its Ecological and Economic Considerations held in Bogor, Indonesia, August 9-11, 1988. BIOTROP Special Publication, No. 37.

Tan C.G.S. and P.K.L. Ng. 1994. An annotated checklist of mangrove brachyuran crabs from Malaysia and Singapore. Hydrobiologia, 285: 75-84.

Vannini M., Oluoch A. and R.K. Ruwa. 1997. The tree-climbing crabs of Kenyan mangroves. In Mangrove ecosystems Studies in Latin America and Africa (B. Kjerfve, B.L. De Lacerda and E.S. Diop, eds.), pp. 325-338. UNESCO Technical Papers in Marine Sciences. New York: UNESCO.

Ya B.P., Darren C. J. Yeo, and Peter A. Todd. 2008. Feeding Ecology of Two Species of Perisesarma (Crustacea: Decapoda: Brachyura: Sesarmidae) in Mandai Mangroves, Singapore. Journal of Crustacean Biology, 28(3):480-484. 
Thank you for evaluating AnyBizSoft PDF Splitter.

A watermark is added at the end of each output PDF file.

To remove the watermark, you need to purchase the software from

http://www.anypdftools.com/buy/buy-pdf-splitter.html 